\title{
DIGITAL TOURISM MUSEUM NASIONAL INDONESIA MELALUI VIRTUAL TOUR DI MASA PANDEMI COVID-19
}

\author{
Bagus Dwi Bramantyo ${ }^{1 *}$, Pitoyo Ismail ${ }^{2}$ \\ ${ }^{1,2}$ Universitas Gunadarma, Depok, Indonesia \\ *bagusdwibramm@gmail.com \\ Submitted: 24-08-2021, Revision: 08-12-2021, Accepted: 29-12-2021
}

\begin{abstract}
The Covid-19 pandemic that has hit Indonesia has succeeded in forming new adaptations of people's habits, one of which is social distancing. The government has appealed to the public to carry out activities from home. Museum Nasional Indonesia as a tourist destination was also affected because it had to close direct visit services. However, Museum Nasional Indonesia provides innovation by utilizing digital tourism, namely through virtual museum tours. Later, the public can visit the Museum Nasional Indonesia virtually. The purpose of this study is to find out Digital Tourism at Museum Nasional Indonesia through Virtual Tours during the Covid-19 Pandemic Period. This research uses a case study method with a qualitative approach and constructivism paradigm. This research uses diffusion of innovation theory from Everett $M$. Rogers, which explains how to introduce and adapt an innovation by a community or group to society. The results of this study indicate that virtual museum tours are a way for Museum Nasional Indonesia to continue to reach and provide museum services to the public, of course, so that they remain interested and can visit museums during the Covid-19 pandemic.
\end{abstract}

Keywords: Digital Tourism, Virtual Tour, Museum Nasional, Covid-19 Pandemic, Diffusion of Innovation

\begin{abstract}
Abstrak
Pandemi Covid-19 yang melanda Indonesia telah berhasil membentuk adaptasi baru dari kebiasaan masyarakat, salah satunya adalah social distancing. Pemerintah telah menghimbau kepada masyarakat untuk melakukan aktifitas dari rumah. Museum Nasional Indonesia sebagai salah satu tempat destinasi wisata juga turut terkena dampak, karena harus menutup layanan kunjungan langsung. Namun Museum Nasional Indonesia memberikan inovasi dengan memanfaatkan digital tourism, yaitu melalui virtual tour museum. Virtual tour museum ini memungkinkan masyarakat untuk dapat melakukan kunjungan secara virtual ke Museum Nasional Indonesia. Tujuan dari penelitian ini adalah untuk mengetahui Digital Tourism Museum Nasional Indonesia Melalui Virtual Tour Di Masa Pandemi Covid-19. Penelitian ini menggunakan metode studi kasus dengan pendekatan kualitatif dan berdasarkan paradigma konstruktivisme. Adapun penelitian ini menggunakan teori difusi inovasi Everett M. Rogers yang menjelaskan mengenai cara pengenalan dan adaptasi dari suatu inovasi oleh suatu komunitas atau kelompok kepada masyarakat. Hasil penelitian menunjukkan jika virtual tour museum merupakan suatu bentuk digital tourism yang telah berhasil dilakukan oleh Museum Nasional Indonesia untuk menjangkau masyarakat lebih luas di masa pandemi Covid-19 ini agar mereka tertarik berkunjung ke museum secara virtual.
\end{abstract}

Kata Kunci: Digital Tourism, Virtual Tour, Museum Nasional, Pandemi Covid-19, Difusi Inovasi

\section{PENDAHULUAN}

Museum merupakan salah satu objek wisata yang memiliki daya tarik tersendiri bagi masyarakat. Pada umunya museum merupakan salah satu tempat untuk menyimpan berbagai macam koleksi peninggalan bersejarah maupun peradaban dari masa lampau yang memiliki nilai-nilai sejarah dan budaya (Sinurat, 2020). Terlebih lagi Indonesia merupakan salah satu negara 
yang memiliki aneka ragam budaya dan perjalanan sejarah yang panjang dari satu masa ke masa berikutnya. Maka tidak heran jika terdapat banyak museum yang ada di Indonesia. Menurut Kotler (2008) museum juga memiliki tujuan untuk merawat dan menyelenggarakan event maupun pameran dari koleksi museum untuk ditunjukkan kepada masyarakat luas, serta dilakukan secara berkala (rutin) dan terbuka.

International Council of Museum memberikan definisi museum sebagai sebuah lembaga nirlaba yang memperoleh, melestarikan, meneliti, mengomunikasikan, dan memamerkan warisan budaya budaya maupun seni yang berwujud dan tidak berwujud kepada masyarakat serta lingkungannya untuk tujuan studi, pendidikan, dan rekreasi dengan martabat dan keadilan sosial (Small, 2019). Sedangkan menurut Perarturan Pemerintah Nomor 19 Tahun 1995: dalam Pedoman Museum Indonesia tahun 2008 menjelaskan jika museum memiliki dua fungsi utama, yaitu sebagai tempat pelestarian dan perawatan koleksi benda cagar budaya serta sebagai sumber informasi dengan melaksankan kegiatan pemanfaatan melalui penelitian dan penyajian kepada masyarakat.

Museum juga dapat di definisikan sebagai pariwisata budaya, yang merupakan suatu aktivitas bagi wisatawan untuk mengetahui maupun memperoleh suatu pengalaman tentang perbedaan cara hidup masyarakat lain yang telah direfleksikan dalam adat istiadat, tradisi, dan ritus dengan nilai-nilai serta warisan budaya yang belum pernah mereka ketahui sebelumnya (Salam, 2019). Richard (Musthofa, 2019) menjelaskan wisata budaya secara sederhana sebagai suatu kunjungan dari beberapa orang ke suatu tempat- tempat wisata budaya dengan didorong juga oleh keinginan untuk mengumpulkan informasi serta pengalaman guna memenuhi kebutuhan budaya mereka sendiri.

Shaw (Salam, 2019) mengatakan jika terdapat sepuluh elemen budaya yang dapat menjadi daya tarik wisata untuk masyarakat, diantaranya adalah tradisi, kerajinan, arsitektur daerah, makanan lokal, sejarah maupun peninggalan dari suatu daerah, seni maupun musik, pandangan maupun cara hidup masyarakat, agama, bahasa, dan pakaian (daerah) tradisional. Dalam konteks yang lebih mendalam, wisata budaya bukan hanya kegiatan seseorang mengunjungi monumen maupun situs saja, tetapi ketika seseorang tersebut dapat menikmati maupun memperhatikan tentang bagaimana cara hidup dari sekelompok orang melalui tempat tujuan wisatanya maupun peninggalan atau koleksi dari masa lampau, itu juga termasuk dalam kategori wisata budaya. Maka dari itu wisata budaya bukan hanya tentang bagaimana cara seseorang mengonsumsi suatu produk di masa lalu, namun juga berkaitan dengan cara hidup kontemporer dan budaya masyarakat di luar lingkungannya (Mousavi, 2016).

Menurut Mappi (Prasodjo, 2017) menjelaskan jika terdapat beberapa aspek yang termasuk dalam ciri-ciri kategori dari objek wisata budaya, diantaranya yaitu: (1) Upacara Tradisional; (2) Tarian Tradisional; (3) Pakaian dan Kain Tradisional; (4) Musik Tradisional; (5) Pernikahan Adat; (6) Bangunan dan Peninggalan Bersejarah; (7) Hasil Tekstil Lokal; (8) Cagar Budaya; (9) Pertunjukkan Tradisional; (10) Pameran Festival Budaya; (11) Museum Sejarah dan Budaya; dan (12) Adat-Istiadat Tradisional Lainnya.

Secara tidak langsung, kehadiran museum telah mendorong aktivitas pariwisata budaya kepada masyarakat. Museum telah berhasil menjadi suatu wadah maupun tempat pembelajaran dan riset bagi masyarakat umum yang memiliki ketertarikan untuk mengetahui maupun mempelajari kesenian budaya, adat-istiadat suatu daerah, peninggalan maupun cara hidup suatu masyarakan di masa lampau (Mayasari, 2018). Namun dalam hasil Rapat Koordinasi Pengelolaan Museum untuk Generasi Milenial yang dilakukan pada 
tahun 2018, memberikan fakta jika minat kunjungan masyarakat ke museum masih sangat rendah. Menurut hasil pertemuan itu, salah satu faktor utamanya adalah masyarakat merasa jika museum masih belum melakukan pendekatan dengan baik, seperti menggunakan media baru untuk menarik minat mereka untuk berkunjung ke museum ("Kunjungan Museum Rendah, Ini Salah Satu Solusinya," 2020).

Padahal menurut data dari Statistik Kebudayaan Indonesia tahun 2021 yang telah dikeluarkan oleh Pusat Data dan Teknologi Informasi Sekeretariat Jenderal Kementerian Pendidikan dan Kebudayaan, saat ini Indonesia sudah memiliki 439 museum yang tersebar hampir di setiap provinsi (Kemendikbud, 2021).

Terlebih pada masa pandemi Covid-19 ini, banyak tempat wisata dimana salah satunya adalah museum yang harus ditutup terlebih dahulu untuk memutus rantai penyebaran virus Covid-19 di Indonesia. Salah satu museum yang mengalami jumlah penurunan drastis dari pengunjung selama pandemi ini adalah Museum Nasional Indonesia, di Jakarta. Namun pengelola Museum Nasional Indonesia memberikan inovasi dan tawaran baru bagi para pengunjungnya, yaitu dengan menyediakan kunjungan secara virtual melalui website resmi museum. Menteri Pendidikan, Kebudayaan, Riset, dan Teknologi Republik Indonesia, Nadiem Anwar Makarim menjelaskan jika saat ini Kemendikbudristek telah melakukan kerjasama dengan Google dan memasukkan 16 museum di Indonesia ke dalam platform Google Arts \& Culture, salah satunya adalah Museum Nasional Indonesia (Ramadhian, 2020).

Virtual Tour museum merupakan suatu hasil dari gabungan antara konsep museum secara fisik dengan konsep komputer multimedia dengan didukung oleh perkembangan teknologi komunikasi (Wulandari, 2021). Keene (Schweibenz, 2019) berpendapat jika kunjungan virtual ke museum bukan sebagai untuk menghilangkan semua fungsi tradisionalnya (kunjungan langsung), tetapi guna menyampaikan tujuan dari museum tersebut dengan menggunakan sarana elektronik. Sedangkan menurut Mintz (Schweibenz, 2019) mengatakan jika kunjungan virtual ke museum adalah sebuah pengalaman dan bentuk komunikasi dalam media baru (new media).

Wulandari (2021) melalui penelitianya yang berjudul "Virtual Tour Sebagai Media Komunikasi Digital Dalam Pelayanan Museum Kehutanan Di Masa Pandemi Covid-19" menjelaskan jika hasil penelitian tersebut menunjukkan jika pandemi Covid19 telah membuat pengelola museum perlu melakukan transformasi digital dalam memberikan pelayanannya kepada publik. Dalam konteks ini, Museum Kehutanan telah berhasil memanfaatkan media komunikasi digital berupa virtual tour untuk memfasilitasi kunjungan dari masyarakat secara daring. Virtual tour tersebut dilakukan dengan aplikasi zoom dan penyebaran informasi dilakukan melalui media sosial.

Berdasarkan penelitian (Syarifuddin, 2017) dengan judul "Virtual Museum: A Learning Material of Indonesia National History" menjelaskan jika hasil penelitian menunjukkan bahwa dengan menggunakan virtual museum, siswa dapat memperoleh pengalaman tidak langsung pada proses pembelajaran secara daring. Selain itu virtual museum juga dapat menghemat waktu serta biaya yang lebih murah dibandingkan ketika pengunjung melakukan kunjungan secara langsung ke museum.

Sedangkan menurut penelitian Schweibenz (2019) dengan judul "The Virtual Museum: An Overview of It's Origins, Concepts, and Terminology" menjelaskan hasil penilitian yang menunjukkan jika konsep inti dari virtual museum merupakan sesuatu yang akan terus berkembang kedepannya. Dalam konteks penelitian ini, hal tersebut akan menjadi 
penting karena dalam waktu dekat bahkan kini pun sudah mulai terjadi pergeseran pengetahuan dan pengalaman karena seluruh generasi mulai menggunakan kegiatan yang didukung dengan teknologi virtual digital dalam berinteraksi. Pada masa depan nanti, museum akan memiliki karakter ganda dimana tetap harus mengemas agar kegiatan kunjungan secara langsung dapat menarik, namun juga harus tetap mengikuti perubahan zaman yang serba digital dengan memiliki program virtual museum.

Keberhasilan Museum Nasional Indonesia menerapkan virtual tour bagi pengunjung, tidak lepas dari perkembangan teknologi digital dalam bidang komunikasi di era sekarang ini. Era digitalisasi ini telah berhasil merubah cara dan perilaku masyarakat dalam melakukan komunikasi. Perkembangan teknologi digital telah membawa manusia pada babak baru dalam realitas kehidupan dengan segala kemudahan dalam membangun maupun memberikan interaksi dan pertukaran informasi (Prasetya, 2013).

Hal tersebut terjadi karena masyarakat dapat langsung saling terhubung dan masuk dalam lingkungan digital hanya dengan bantuan suatu perangkat/gawai yang terhubung oleh koneksi internet saja. Era digitalisasi di masa ini telah memberikan kemungkinan untuk melahirkan bentuk baru dari suatu organisasi untuk memproduksi maupun memperkenalkan sesuatu, baik produk maupun jasa secara terorganisir dan saling terhubung dalam suatu basis jaringan informasi elektronik (Anwar, 2017).

Perkembangan dan inovasi dalam dunia digital seperti virtual tour museum ini sangat berkaitan dengan teori difusi inovasi. Teori difusi inovasi pertama kali diperkenalkan oleh Everett M. Rogers, yang mencoba menjelaskan tentang cara pengenalan dan adaptasi dari suatu inovasi oleh suatu komunitas atau kelompok sosial (Haryadi, 2018). Difusi inovasi juga merupakan salah satu teori komunikasi yang cukup sering digunakan dalam berbagai topik tema mengenai sosialisasi ide-ide baru, dimana pada konteks penelitian ini peneliti juga akan menggunakan teori ini karena memang virtual tour pada museum merupakan salah satu bentuk dari inovasi dan ide baru untuk masyarakat dalam mengunjungi museum. Menurut Rogers (Sutjipto, 2019) dijelaskan sebagai suatu ide, kegiatan maupun objek yang memiliki unsur kebaruan di dalamnya.

Rogers (Sutjipto, 2019) mengatakan jika difusi inovasi tidak hanya terjadi begitu saja, namun terdapat empat elemen utama yang saling mempengaruhi satu dengan lainnya, yaitu: (1) Inovasi, dimana secara umum dipahami sebagai konteks yang melibatkan perubahan sesuatu yang lebih baru; (2) Saluran Komunikasi, merupakan penghubung antara komunikator dan komunikan dalam menyampaikan pesan. Dalam konteks ini salurang komunikasi di kelompokan menjadi dua, yaitu media massa dan komunikasi interpersonal, dengan beberapa kekurang dan kelebihannya tersendiri; (3) Waktu, meliputi segala rangkaian saat ketika proses, perbuatan, atau keadaan sedang berlangsung; (4) Sistem Sosial, dapat didefinisikan sebagai sekumpulan unit yang saling berhubungan dan terlibat dalam memecahkan suatu masalah dengan tujuan untuk mencapai tujuan.

Selain itu Rogers (Rusmiarti, 2015) juga menjelaskan jika difusi inovasi merupakan suatu proses bagaimana sebuah inovasi dapat dikomunikasikan melalui channel tertentu kepada audiens atau anggota kelompok dari suatu sistem sosial. Dalam teori ini, media menjadi wadah utama dalam penyampaian informasi, selain itu media memiliki peranan penting dalam dalam promosi difusi dan adopsi terhadap inovasi sosial dan teknis yang berkaitan dengan modernisasi (Santoso, 2016). Rogers dan Shoemaker (Daryanto, 2014) menjelaskan jika terdapat empat proses tahapan dari difusi inovasi, yaitu: (1) Pengetahuan: meliputi kesadaran setiap individu terhadap adanya inovasi dan fungsi dari inovasi 
tersebut; (2) Persuasi: meliputi sikap individu dalam menerima atau tidak menerima inovasi tersebut; (3) Decision: meliputi peran individu dalam menentukan pilihan untuk mengadopsi atau menolak inovasi; dan (4) Konfirmasi: meliputi peran individu dalam mencari pendapat yang memberikan pengaruh besar terhadap keputusan yang telah diambilnya, serta bersifat fleksibel (bisa berubah) jika pesan dalam inovasi yang diterima berlawanan antara satu dengan yang lain.

\section{METODOLOGI}

Penelitian ini menggunakan pendekatan kualitatif dengan metode studi kasus yang memiliki fokus penelitian mengenai spesifikasi suatu kasus dalam sebuah kejadian baik itu mencakup individu, kelompok budaya, maupun sebuah potret terhadap kehidupan (Imran, 2015). Penelitian ini jugaka menggunakan paradigma konstruktivisme yang menjelaskan jika realitas itu ada dalam beragam bentuk konstruksi yang telah didasarkan pada pengalaman sosial, baik bersifat lokal maupun spesifik. Penelitian yang memakai paradigma konstruktivisme memiliki tujuan untuk memahami kejadian maupun peristiwa sosial yang terjadi. Neuman (2016) menjelaskan jika paradigma konstruktivisme merupakan suatu upaya untuk memahami serta menjelaskan tindakan sosial yang dilakukan oleh seorang individu maupun kelompok sosial secara bermakna.

Metode pengumpulan data pada penelitian ini terdiri dari wawancara peneliti dengan pengelola Museum Nasional Indonesia dan beberapa masyarakat yang telah melakukan kunjungan secara virtual di Museum Nasional Indonesia. Selain melakukan wawancara, peneliti juga melakukan observasi guna mendapatkan beberapa data yang tidak peneliti temukan ketika wawancara dengan informan. Adapun dalam penelitian ini tempat yang peneliti observasi adalah dengan melakukan kunjungan langsung ke Museum Nasional Indonesia dan juga melalui kunjungan virtual di website resminya.

Teknik analisis data pada penelitian ini merujuk pada langkah-langkah menurut Robert K. Yin, yang merupakan seorang pakar penelitian mengenai studi kasus. Robert K. Yin (Wahyuningsih, 2013) membagi tiga langkah teknik analisis untuk studi kasus. Langkah pertama adalah penjodohan pola, dimana peneliti mencoba membandingkan pola yang telah didasarkan pada data empirik dengan pola yang telah diprediksikan (dapat dengan beberapa alternatif). Jika kedua pola ini memiliki persamaan, hasilnya dapat menguatkan validitas internal dari studi kasus yang terjadi. Langkah kedua ada pembuatan eksplanasi yang bertujuan untuk menganalisis data studi kasus yang telah didapatkan. Kemudian langkah ketiga adalah analisis deret waktu, langkah ini seringkali dipergunakan pada penelitian studi kasus dengan menggunakan pendekatan eksperimen.

Selain mewawancarai pengelola Museum Nasional Indonesia untuk menjelaskan bagaimana langkah maupun keputusan yang mereka ambil agar museum masih tetap hidup ditengah pandemi Covid19 ini, adapun dalam penelitian ini peneliti juga melakukan eksperimen dengan meminta beberapa orang yang belum pernah mengunjungi Museum Nasional secara langsung, untuk mengunjungi virtual tour di museum tersebut. Creswell (Wahyuningsih, 2013) menjelaskan jika dalam penelitian studi kasus seorang peneliti perlu melibatkan pengumpulan data yang banyak, karena pada dasarnya peneliti akan mencoba untuk memberikan gambaran yang mendalam dari suatu kasus tersebut. Hingga pada nantinya peneliti akan menarik kesimpulan berdasarkan gambaran pengalaman mereka setelah melakukan virtual tour di Museum Nasional Indonesia. 


\section{HASIL DAN PEMBAHASAN}

Dalam penelitian ini, peneliti telah mewawancarai dua staff Museum Nasional Indonesia yang memiliki peran penting dalam perencanaan dan strategi digital komunikasi Museum Nasional virtual tour, yaitu: Asep Firman, sebagai Pamong Ahli Budaya Museum Nasional dan Ujang Mulyadi, sebagai Divisi Produksi Program Publik Museum Nasional. Selain itu peneliti juga telah melakukan wawancara kepada lima orang informan yaitu: Fona, Chika, Tasya, Afif, dan Teguh yang telah mengunjungi Museum Nasional secara virtual selama pandemi Covid-19 ini.

Dua kriteria informan yang berbeda ini peneliti wawancarai demi mendapatkan data lebih variatif dengan sudut pandang yang berbeda, sekaligus untuk melakukan perbandingan maupun kecocokan data antara inovasi maupun informasi yang telah dilakukan Museum Nasional melalui virtual tour dengan beberapa masyarakat yang telah mengunjungi museum tersebut secara virtual dan peneliti bisa mendapatkan data dari experience mereka terhadap fitur tersebut, apakah sudah cukup memberikan alternatif yang baik dalam mengunjungi museum di masa pandemi Covid-19 ini.

\section{Museum Nasional Sebagai Media Pembelajaran}

Musem Nasional Indonesia merupakan sebuah museum arkeologi, sejarah, etnografi, dan geogradi yang terletak di Jakarta Pusat. Museum ini menjadi museum pertama dan terbesar di Asia Tenggara yang sudah berdiri sejak 24 April 1778. Museum ini juga dikenal dengan nama Museum Gajah, hal tersebut di latar belakangi karena pada halaman depan Museum Nasional terdapat patung gajah berbahan perunggu yang diberikan oleh Raja Chulalongkorn dari Thailand pada tahun 1871 (Adryamarthanino, 2021). Museum masih menjadi salah satu media untuk pembelajaran, khususnya bagi sekolah maupun mahasiswa yang memiliki kebutuhan dalam konteks bidang pendidikan maupun penelitian. Penggunaan media pembelajaran yang tepat dapat membantu menciptakan suasana belajar yang menyenangkan (enjoyable learning) serta mendorong proses pembelajaran yang aktif, kreatif, dan efektif.

Menggunakan media pembelajaran yang tepat juga dapat menimbulkan kesadaran pada peserta didik untuk dapat belajar mengetahui (learning to know), belajar berkarya (learning to do), belajar untuk menjadi diri sendiri (learning to be), dan belajar untuk hidup bersama orang lain secara harmonis (learning to live together) (Karyono, 2010). Sebelum masa pandemi Covid-19, Maseum Nasional Indonesia seringkali menerima kunjungan study tour dari beberapa sekolah di wilayah Jabodetabek. Disana nantinya para siswa akan di pandu dan diajak untuk mengelilingi serta melihat isi dari koleksi museum tersebut. Selain mendapatkan pembelajaran di museum, para siswa juga dapat merasakan wisata edukasi dengan berkunjung disana. Dengan masih banyaknya sekolah yang tertarik untuk membuat agenda kunjungan ke Museum Nasional dalam kurikulum pendidikannya, secara tidak langsung ini juga membuktikan jika museum masih menjadi salah satu media favorit untuk pembelajaran dalam konteks pendidikan di sekolah

\section{Difusi Inovasi Museum Nasional Melalui Virtual Tour}

Sejak Indonesia di landa pandemi Covid-19 pada awal Maret 2020 lalu, pemerintah memutuskan untuk mengambil langkah konkrit dengan menutup berbagai destinasi wisata di Indonesia, salah satunya adalah museum. Selain itu pemerintah juga menetapkan PSBB (Pembatasan Sosial Berskala Besar) bagi masyarakat, dengan tujuan untuk membatasi ruang gerak masyarakat dan bisa mencegah maupun mengurangi kemungkinan penyebaran virus Covid-19. Ketika hal tersebut terjadi, Museum Nasional Indonesia melakukan 
inovasi dengan kembali mempromosikan virtual tour museum kepada publik. Difusi inovasi sendiri merupakan sebuah teori yang menjelaskan mengenai cara pengenalan dan adaptasi dari suatu inovasi oleh suatu komunitas atau kelompok sosial (Haryadi, 2018).

Rogers (Sutjipto, 2019) mengatakan jika difusi inovasi tidak hanya terjadi begitu saja, namun terdapat empat elemen utama yang saling mempengaruhi satu dengan lainnya. Elemen pertama dalam difusi inovasi adalah adanya inovasi itu sendiri. Pada penelitian ini, virtual tour museum merupakan suatu hasil dari pembaharuan ide yang dilakukan Museum Nasional ketika melihat referensi virtual tour dari museummuseum di luar negeri seperti eropa, dimana pada fitur tersebut dipadukan oleh hasil dari tampilan pada google street view. Ujang Mulyadi selaku Divisi Produksi Program Publik Museum Nasional kemudian tertarik menerapkan konsep tersebut di Museum Nasional. Beliau menjelaskan jika sebenarnya virtual tour museum ini sudah di launching sejak tahun 2015 lalu oleh Museum Nasional. Namun ketika mereka mengumumkan virtual tour museum ini ke media, program virtual tour museum ini masih mendapatkan respon yang kurang dari masyarakat. Menurut Asep Firman selaku Pamong Ahli Budaya Museum Nasional, saat itu perkembangan teknologi belum semasif sekarang, bahkan masyarakat yang menggunakan video conference juga belum banyak. Kemudian pada saat itu situasi dan kondisi yang terjadi juga masih sangat mendukung bagi masyarakat untuk melakukan kunjungan secara langsung. Walaupun jika dilihat dari datanya saat itu, virtual tour museum lebin banyak diakses oleh turis mancanegara.

Namun ketika Indonesia dilanda pandemi Covid-19, Asep Firman mengatakan jika mulai banyak masyarakat yang merindukan berkunjung ke museum. Sehingga mulai saat itu virtual tour Museum Nasional mulai memiliki banyak pengunjungan, terutama bagi sekolahsekolah yang bekerja sama dengan Museum Nasional untuk melakukan virtual tour museum secara streaming melalui aplikasi zoom meeting.

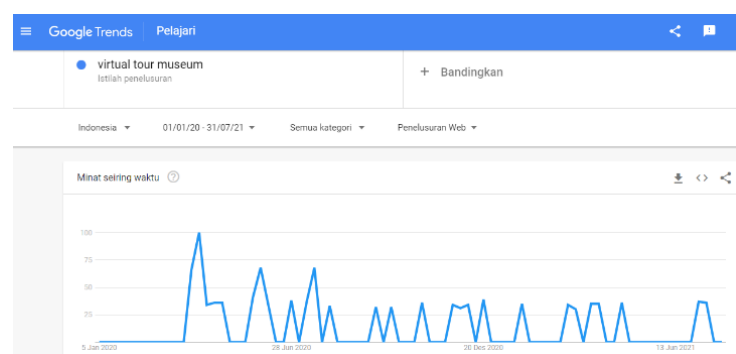

Gambar 1. Google Trends Virtual Tour (Sumber: Google Trends, 2021)

Berdasarkan data penelusuran yang telah peneliti lakukan melalui perangkat Google Trends yang merupakan sebuah layanan dari Google yang menyediakan data dan grafik mengenai popularitas maupun trend yang sedang terjadi di halaman pencarian Google. Berdasarkan data penelusuran mengenai "virtual tour museum" di atas telah berhasil menunjukkan hasil jika sejak bulan Januari 2021 sampai dengan Juli 2021, minat masyarakat di Indonesia terhadap fitur ini mulai mengalami kenaikan yang cukup signifikan, terutama pada akhir bulan Maret 2021 hingga pertengahan bulan Juli 2021. Sedangkan topik terkait mengenai "virtual tour museum" dalam Google Trends ini menempatkan Museum Nasional Indonesia pada posisi ke-4 dalam data tersebut.

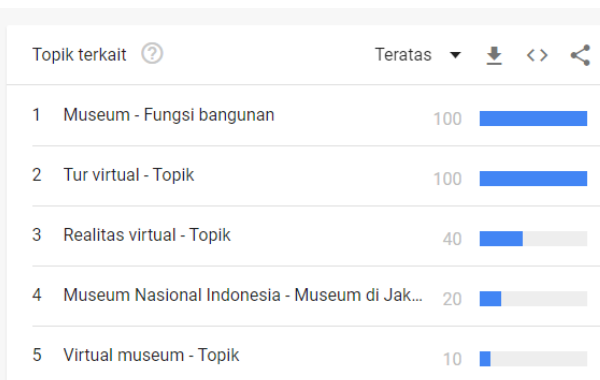

Gambar 2. Google Trends Topik Terkait Virtual Tour

(Sumber: Google Trends, 2021) 
Lebih lanjut lagi, Ujang Mulyadi selaku Divisi Produksi Program Publik mengatakan jika sebenarnya virtual tour Museum Nasional Indonesia memiliki dua skema operasional. Dimana skema pertama adalah virtual tour museum yang diagendakan bersama sekolah-sekolah yang telah bekerja sama dengan Museum Nasional Indonesia. Jadi nantinya Museum Nasional Indonesia akan mengadakan streaming virtual tour museum bersama dari para siswa sekolah tersebut dengan menggunakan aplikasi zoom meeting. Selain itu didalam virtual tour museum tersebut juga akan dipandu oleh seorang pamong budaya dari Museum Nasional. Kemudian nantinya para siswa akan diajak untuk mengelilingi dan melihat isi koleksi museum secara virtual. Setelah melakukan virtual tour museum akan ada disksusi terbuka dari guru dan pemandu dari Museum Nasional Indonesia kepada para siswa. Lalu skema kedua adalah virtual tour museum secara mandiri. Dalam konteks ini, para pengunjung dapat mengakses langsung menu virtual tour museum pada website resmi Museum Nasional Indonesia. Artinya dalam virtual tour museum secara mandiri ini para pengunjung tidak akan dipandu dalam mengelilingi dan melihat isi koleksi di museum tersebut. Tetapi dalam fitur virtual tour museum tersebut telah ditambahkan audio penjelasan mengenai koleksi dari Museum Nasional Indonesia.

Selanjutnya elemen kedua dalam difusi inovasi kedua adalah memiliki saluran komunikasi. Dalam mempromosikan program virtual tour museum, saluran komunikasi yang digunakan oleh Museum Nasional adalah sosial media seperti Instagram, Facebook, dan Youtube.

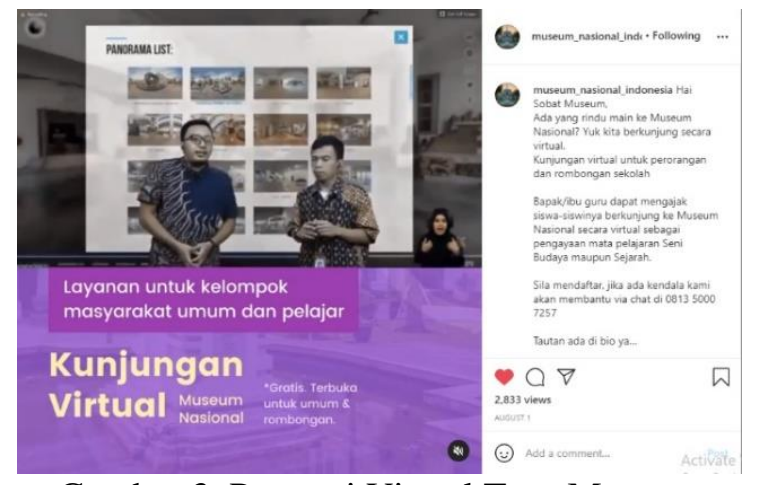

Gambar 3. Promosi Virtual Tour Museum (Instagram)

(Sumber: Dokumentasi Peneliti, 2021)

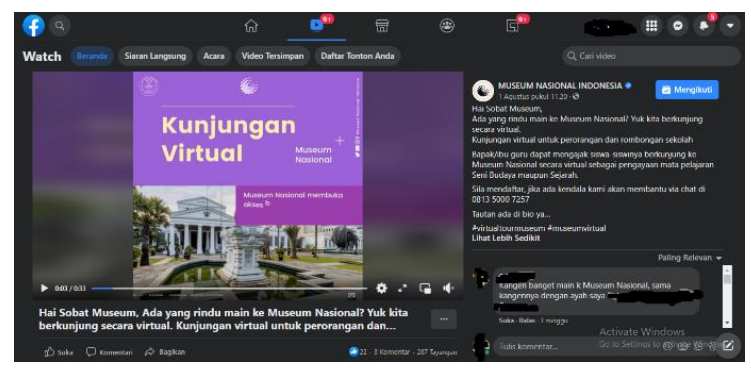

Gambar 4. Promosi Virtual Tour Museum (Instagram)

(Sumber: Dokumentasi Peneliti, 2021)

Museum Nasional sering melakukan promosi mengenai kegiatan program ini melalui sosial media mereka. Dimana pada setiap hari Jumat pukul 14.00 WIB siang, Museum Nasional memiliki jadwal secara rutin untuk kunjungan virtual museum yang dipandu oleh seorang pamong ahli budaya dan program ini dibuka secara umum, dimana artinya seluruh masyarakat baik pelajar, mahasiswa, hingga para pendidik seperti guru pun bisa mengikuti pemanduan daring ini. Peneliti sendiri sempat mengikuti program pemanduan tersebut diikuti oleh kurang lebih 18 pengunjung dan sesi pemanduan program virtual tour museum ini berjalan dengan sangat interaktif dari para pengunjung. 


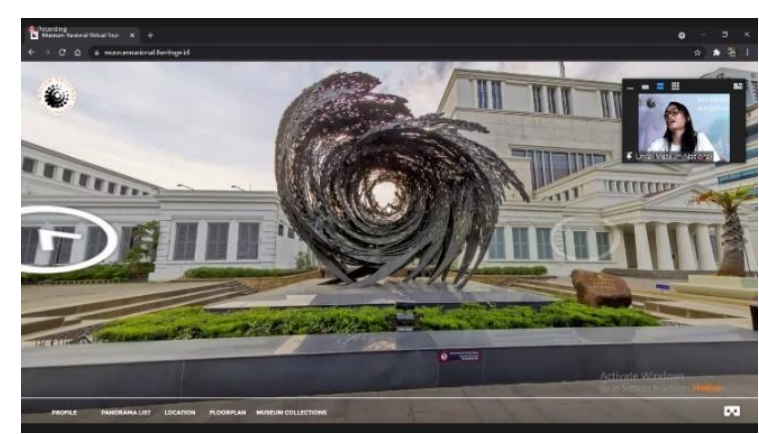

Gambar 5. Pemanduan Virtual Tour Museum

(Sumber: Dokumentasi Peneliti, 2021)

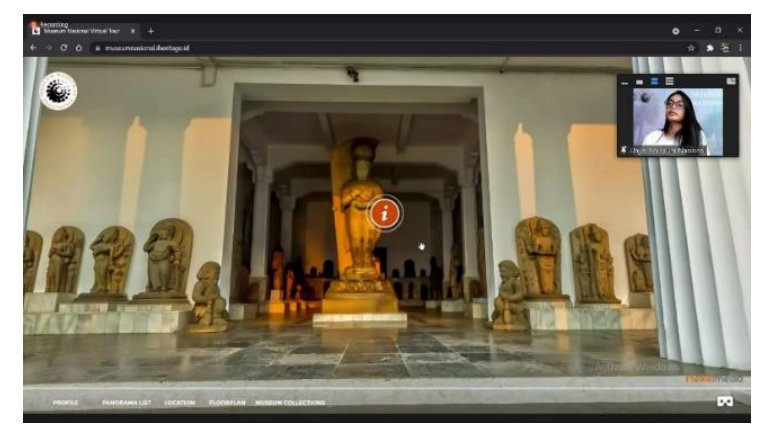

Gambar 6. Pemanduan Virtual Tour Museum (Koleksi Arca)

(Sumber: Dokumentasi Peneliti, 2021

Lalu elemen ketiga dalam difusi inovasi adalah memiliki jangka waktu tertentu. Dimana umumnya sebuah difusi inovasi memang biasanya muncul dalam suatu jangka waktu tertentu. Seperti yang telah peneliti jelaskan diatas bahwa sebenarnya program untuk fitur ini sudah di desain sejak tahun 2015, namun baru mendapatkan atensi/perhatian dari masyarakat sejak pandemi Covid-19 melanda Indonesia dan kedekatan manusia dengan teknologi digital sudah sangat erat. Hal tersebut sejalan dengan penelitian dari Werner Scheibenz pada tahun 2019 dengan judul penelitian "The Virtual Museum: An Overview of It's Origins, Concept, and Terminology" dimana pada hasil penelitian tersebut menjelaskan jika virtual museum tampaknya memang akan menjadi esensi yang penting bagi masyarakat, karena memang pada masa akan datang akan terjadi pergeseran 66 pengetahuan maupun pengalaman dari seluruh generasi ke era digitalsasi.
Kemudian elemen keempat adalah sistem sosial, dimana sebuah inovasi juga perlu memiliki sasaran tertentu dengan tujuan agar difusi inovasi dapat berjalan. Pada penelitian ini, sistem sosial yang menjadi sasaran adalah masyarakat yang menginginkan aktivitas mengunjungi sesuatu tanpa perlu keluar rumah, karena memang pada dasarnya situasi dan kondisi pada masa pandemi Covid-19 memang mengharuskan masyarakat agar tetap beraktivitas dirumah. Selanjutnya adalah para siswa yang harus tetap mendapatkan akses pendidikan di sekolah, seperti dengan wisata edukasi melalui virtual tour museum.

\section{Proses Inovasi Pada Virtual Tour Museum Nasional}

Sebelum menentukan keputusan terhadap suatu inovasi, seorang adopter membutuhkan suatu proses waktu berdasarkan serangkaian tindakan terlebih dahulu, dimana hal tersebut tentunya juga terjadi pada para pengunjung yang melakukan virtual tour museum, Rogers dan Shoemaker (Daryanto, 2014) menjelaskan jika terdapat empat proses tahapan dari difusi inovasi. Pertama adalah pengetahuan yang meliputi kesadaran setiap individu terhadap adanya inovasi dan fungsi dari inovasi tersebut. Pada penelitian ini, salah satu peneliti yang telah melakukan virtual tour museum, yaitu Fona berpendapat jika Museum Nasional telah melakukan langkah yang cukup tepat agar masyarakat tetap dapat melakukan kunjungan ke museum di tengah wabah pandemi Covid-19. Terlebih pada masa pandemi Covid-19 ini berbagai ruang gerak masyarakat menjadi terbatas, sehingga virtual tour museum merupakan suatu langkah cukup baik bagi mereka, sekaligus dapat menimalisir cost dan waktu yang digunakan untuk tujuan tersebut. Asep Firman selaku Pamong Ahli Budaya mengatakan, memang pada prinsip tujuan virtual tour museum ditunjukkan bagi para pengunjung yang ingin mengunjungi Museum Nasional namun terkendala teknis 
seperti jarak maupun situasi yang tidak memungkinkan dirinya bisa datang dan berkunjung secara langsung.

Kedua adalah persuasi yang meliputi sikap individu dalam menerima atau tidak menerima inovasi tersebut. Pada penelitian ini para informan menyampaikan jika virtual tour museum merupakan suatu bentuk dari modernisasi bagi sebuah museum. Salah satu informan yang telah melakukan kunjungan virtual tour yaitu Afif memberikan penafsiran jika fitur ini bisa juga dijadikan salah satu cara bagi Museum Nasional untuk melakukan promosi lebih luas kepada publik, agar mereka mengetahui museum ini. Selanjutnya Afif memberikan sebuah analogi seperti ketika seseorang ingin melakukan liburan ke suatu tempat, mereka akan cenderung mencari referensi melalui digital, entah itu melalui video vlog, tulisan review, dan foto-foto di sosial media, lalu kemudian dirinya baru menentukan apakah jadi ingin berlibur di tempat tersebut. Dimana proses persuasi dari inovasi virtual tour museum ini juga mengalami pola yang sama, nantinya mereka akan mencari tahu informasi sebanyak-banyaknya terlebih dahulu sebelum menentukan sikap maupun perilaku kedepannya mengenai fitur ini.

Kemudian yang ketiga adalah decision dimana meliputi peran individu dalam menentukan pilihan untuk mengadopsi atau menolak inovasi. Pada penelitian ini para informan yang telah melakukan virtual tour museum memilih untuk melakukan kunjungan tersebut dikarenakan memang ada banyak faktor yang mempengaruhi mereka, seperti halnya ketertarikan, kesamaan kondisi saat ini di masa pandemi Covid-19, dan melakukan self-healing dari rutinitas kesehariannya. Proses pemilihan tersebut juga disebabkan oleh fitur ini memiliki kesan modernisasi yang fresh bagi museum, salah satu informan peneliti yaitu Tasya mengatakan jika modernisasi dari virtual tour museum ini dapat diadopsi pada segala aspek museum lainnya. Bahkan salah satu informan peneliti lainnya yaitu Teguh mengatakan jika dirinya kembali menjadi tertarik untuk berkunjung ke museum secara langsung selepas pandemi Covid-19 selesai setelah melihat dan berkunjung ke Museum Nasional melalui fitur ini. Hal tersebut disebabkan oleh rasa penasaran lebih bagi dirinya yang belum didapatkan dengan hanya berkunjung secara virtual. Asep Firman selaku Pamong Ahli Budaya Museum Nasional juga mengatakan, jika tujuan lain dari fitur ini memang salah satunya sebagai pemantik bagi masyarakat untuk kembali berkunjung ke museum secara langsung. Karena memang menurutnya ada esensi maupun pengalaman lebih yang tidak bisa didapatkan masyarakat dengan hanya melakukan kunjungan secara virtual.

Lalu yang terakhir adalah konfirmasi yang meliputi peran individu dalam mencari pendapat yang memberikan pengaruh besar terhadap keputusan yang telah diambilnya, serta bersifat fleksibel (bisa berubah) jika pesan dalam inovasi yang diterima berlawanan antara satu dengan yang lain. Pada penelitian ini, bentuk konfirmasi yang dilakukan oleh para informan yang telah melakukan virtual tour museum memang menganggap sudah saatnya bagi museum untuk bertransformasi ke era digital guna mengikuti perkembangan zaman. Sebelum mengetahui adanya fitur ini, salah satu informan peneliti yang telah melakukan virtual tour museum yaitu Arief menganggap museum sebagai suatu tempat yang kuno, sepi, dan ketinggalan zaman. Hal tersebut juga didukung oleh data dari hasil Rapat Koordinasi Pengelolaan Museum untuk Generasi Milenial yang dilakukan pada tahun 2018 ("Kunjungan Museum Rendah, Ini Salah Satu Solusinya," 2020), yang menjelaskan jika salah satu faktor utama masyarakat khususnya milenial masih kurang tertarik ke museum karena museum dianggap masih membosankan dan belum melakukan pendekatan dengan baik kepada masyarakat, seperti menggunakan media baru untuk menarik minat mereka 
berkunjung ke museum. Tetapi dengan adanya virtual tour museum ini secara tidak langsung telah berhasil melakukan pendekatan dan informasi mengenai isi koleksi museum dengan baik kepada masyarakat.

Menurut salah satu informan peneliti yang telah mengunjungi virtual tour museum, yaitu Chika mengatakan jika informasi yang diberikan pada tampilan di fitur sudah cukup baik, walaupun memang menurutnya masih ada beberapa detail koleksi informasi yang belum tersampaikan dengan jelas. Selain itu Chika juga mengatakan jika adanya virtual tour museum ini merupakan sebuah inovasi yang cukup baik, karena telah memudahkan dirinya untuk mengakses dan ingin mengunjungi Museum Nasional. Apa yang disampaikan oleh Chika tersebut sejalan dengan apa yang pernah disampaikan Rogers (Rusmiarti, 2015) dimana difusi inovasi memang suatu proses dari sebuah inovasi agar dapat disampaikan maupun dikomunikasikan melalu channel/media kepada audiens maupun anggota kelompok tertentu dari sebuah sistem sosial.

\section{SIMPULAN}

Pandemi Covid-19 yang melanda Indonesia telah melahirkan beberapa adaptasi baru, salah satunya adalah Digital Tourism yang dilakukan Museum Nasional Indonesia melalui virtual tour. Melalui fitur ini, masyarakat dapat melakukan kunjungan secara virtual (daring). Virtual tour yang ditawarkan Museum Nasional Indonesia memiliki dua skema, yaitu kunjungan virtual yang di agendakan dan telah melakukan kerjasama dengan Museum Nasional Indonesia, dimana nantinya pihak sekolah, organisasi, maupun komunitas akan tergabung dalam sebuah video conference virtual tour dan dipandu langsung oleh salah satu pamong budaya dari Museum Nasional Indonesia. Lalu skema kedua adalah kunjungan virtual secara mandiri, dimana dalam konteks ini pengunjung dapat langsung mengakses virtual tour museum secara gratis di laman website resmi Museum Nasional Indonesia. Virtual tour museum yang dilakukan Museum Nasional Indonesia merupakan salah satu bentuk dari difusi inovasi yang cukup penting, mengingat pada masa pandemi Covid-19 ini ruang gerak masyarakat masih dibatasi guna menghindari kerumunan dan memutus rantai penyebaran virus. Hadirnya virtual tour museun ini telah memberikan adaptasi baru bagi masyarakat yang tetap ingin berwisata ke museum. Karena mereka cukup mengaksesnya melalui device milik mereka dan melakukannya dirumah. Seluruh informan yang pernah melaukan virtual tour museum mengatakan jika fitur ini sangat menarik bagi mereka dan merupakan sebuah inovasi yang sangat baik bagi museum, karena dengan hadirnya fitur ini menunjukkan jika anggapan mengenai museum yang kuno dan konvensional bagi mereka dapat di patahkan. Menurut mereka ini adalah wajah baru bagi museum yang dapat mengikuti perkembangan teknologi dan dapat bertransformasi menjadi lebih modern.

\section{DAFTAR PUSTAKA}

Adryamarthanino, V. (2021). Sejarah Museum Nasional Indonesia. Kompas.Com.

https://www.kompas.com/stori/read/20 21/06/15/190000079/sejarah-museumnasional-indonesia?page $=$ all

Anwar, R. K., \& Rusmana, A. (2017). Komunikasi Digital Berbentuk Media Sosial dalam Meningkatkan Kompetensi Bagi Kepala, Pustakawan, dan Tenaga Pengelola Perpustakaan (Studi kasus pada Sekolah/Madrasah di Desa Kayu Ambon, Kecamatan Lembang Kabupaten Bandung Barat). Jurnal Aplikasi Ipteks Untuk Masyarakat, 6(3), 204-208. http://jurnal.unpad.ac.id/dharmakarya/ article/view/14891/7918

Daryanto. (2014). Teori Komunikasi. 
Gunung Samudera.

Haryadi, T. (2018). Adaptasi Teori DifusiInovasi Dalam Game "Yuk Benahi" Dengan Pendekatan Komunikasi Smcr. Jurnal Audience, 1(1), 1-13. https://doi.org/10.33633/ja.v1i1.2678

Imran, H. A. (2015). Penelitian Komunikasi Pendekatan Kualitatif Berbasis Teks. Jurnal Studi Komunikasi Dan Media, 19(1), 129-139. https://doi.org/10.31445/jskm.2015.19 0109

Karyono. (2010). Pemanfaatan Museum Sebagai Media Pembelajaran Untuk Meningkatkan Pemahaman Siswa Terhadap Materi Prasejarah Bagi Guruguru Sma Kota Semarang. Jurnal Abdimas, 14(1), 1-7. https://journal.unnes.ac.id/nju/index.ph p/abdimas/article/view/16/9

Kemendikbud. (2021). Statistik Kebudayaan 2021. In Kemendikbud. Kementerian Pendidikan Dan Kebudayaan. http://publikasi.data.kemdikbud.go.id/ uploadDir/isi_CC4179A6-B4FF4E0C-809B-5CADD9132AB5_.pdf

Kotler, N. G., Kotler, P., \& Kotler, W. I. (2008). Museum Marketing and Strategy: Designing Missions, Building Audiences, Generating Revenue and Resources. John Wiley \& Sons, Inc. http://books.google.com/books?id=nQ gTAQAAMAAJ\&pgis $=1$

Kunjungan Museum Rendah, Ini Salah Satu Solusinya. (2020). Warta Ekonomi. https://www.wartaekonomi.co.id/read3 17582/kunjungan-museum-rendah-inisalah-satu-solusinya

Mayasari, S., \& Indraswari, C. (2018). Efektivitas Media Sosial Instagram Dalam Publikasi HUT Museum Nasional Indonesia (MNI) Kepada Masyarakat. Jurnal Komunikasi, 9(2), 190-196.

https://ejournal.bsi.ac.id/ejurnal/index. php/jkom/article/view/4326

Mousavi, S. S., Doratli, N., Mousavi, S. N., \& Moradiahari, F. (2016). Defining
Cultural Tourism Seyed. International Conference on Civil, Architecture and Sustainable Development (CASD2016), $\quad 1(2), \quad 70-75$. https://iicbe.org/upload/8607DIR1216 411.pdf

Musthofa, B. M. (2019). Strategi Adaptasi Destinasi Wisata Budaya di Era Disrupsi Teknologi. Jurnal Studi Pariwisata, 12, 421-426. http://ojs.uho.ac.id/index.php/snt2bkl/a rticle/view/9877/7109

Neuman, W. L. (2016). Metodologi Penelitian Sosial, Pendekatan Kualitatif dan Kuantitatif - W Lawrence Neuman Edisi 7. PT Indeks.

Prasetya, H. (2013). VIRTUAL ETNOGRAPHY (Kajian Etnografi Komunikasi Pada Media Sosial Di Indonesia). WACANA: Jurnal Ilmiah Ilmu Komunikasi, 7(4), 355-371. https://journal.moestopo.ac.id/index.ph $\mathrm{p} / \mathrm{wacana} /$ article/view/118

Prasodjo, T. (2017). Pengembangan Pariwisata Budaya dalam Perspektif Pelayanan Publik. Jurnal Office, 3(1), 7-12. https://doi.org/10.26858/jo.v3i1.3448

Ramadhian, N. (2020). Saatnya Virtual Traveling, 16 Museum Digital Indonesia yang Bisa "Dikunjungi." Kompas.Com. https://travel.kompas.com/read/2020/0 3/17/220300227/saatnya-virtualtraveling-16-museum-digitalindonesia-yang-bisadikunjungi?page $=$ all

Rusmiarti, D. A. (2015). Analisis Difusi Inovasi Dan Pengembangan Budaya Kerja Pada Organisasi Birokrasi. Jurnal Masyarakat Telematika Dan Informasi, 6(2), 85-100. https://media.neliti.com/media/publica tions/233782-analisis-difusi-inovasidan-pengembangan-03191809.pdf

Salam, N. E., \& Nurjanah. (2019). Komunikasi Pariwisata Budaya Dalam Mempromosikan City Branding "Siak 
the truly Malay." 4(1), 134-154. http://jurnal.unpad.ac.id/profesihumas/article/view/22235/11430

Santoso, W. M. (2016). Ilmu sosial di Indonesia: Perkembangan dan tantangan. Yayasan Pustaka Obor Indonesia.

Schweibenz, W. (2019). The virtual museum: an overview of its origins , concepts, and terminology. The Museum Review, Volume 4, Number 1, 4(1), undefined-undefined. http://articles.themuseumreview.org/t mr_vol4no1_schweibenz\%0Ahttps://w ww.researchgate.net/publication/3352 41270_The_virtual_museum_an_over view_of_its_origins_concepts_and_ter minology

Sinurat, H., Silvia, I., \& Sabrin. (2020). Strategi Komunikasi Pemasaran dalam Meningkatkan Minat Berkunjung di Museum Negeri Provinsi Sumatera Utara. Message: Jurnal Komunikasi, 9(Vol 9 No 1 (2020): AGUSTUS), 6271.

https://jurnal.darmaagung.ac.id/index. $\mathrm{php} / \mathrm{messageilmukomunikasi/article/vi}$ ew/681

Small, Z. (2019). A New Definition of "Museum" Sparks International Debate. Hyperallergic.Com. https://hyperallergic.com/513858/icom -museum-definition/

Sutjipto, A. M., \& Pinariya, J. M. (2019). Pengenalan Vaksinasi Hpv Oleh Koalisi Indonesia Cegah Kanker Serviks Dengan Pendekatan Teori Difusi Inovasi. WACANA: Jurnal Ilmiah Ilmu Komunikasi, 18(2). https://doi.org/10.32509/wacana.v18i2 .910

Syarifuddin, Syahrial, Z., \& Suparman, A. (2017). International journal of multicultural and multireligious understanding virtual museum: A learning material of Indonesia national history. 4(6), 51-60. http://dx.doi.org/10.18415/ijmmu.v4i6. 96

Wahyuningsih, S. (2013). Metode Penelitian Studi Kasus: Konsep, Teori Pendekatan Psikologi Komunikasi, dan Contoh Penelitiannya. In UTM PRESS Bangkalan - Madura.

Wulandari, Y. F., Caesariano, L., Murtiadi, \& Bastian, Y. (2021). Virtual Tour Sebagai Media Komunikasi Digital Dalam Pelayanan Museum Kehutanan di Masa Pandemi Covid-19. Jurnal Media Penyiaran, 01(01), 9-15. http://jurnal.bsi.ac.id/index.php/jmp/ar ticle/view/389 